\title{
Kepatuhan Mengkonsumsi Tablet Fe Dan Anemia Terhadap Kekurangan Energi Kronik (Kek) Pada Ibu Hamil Tahun 2020 (Studi Literatur)
}

\author{
Yuli Bahriah \\ Akademi Kebidanan Budi Mulia Palembang
}

\author{
Informasi Artikel : \\ Diterima : 10 April 2021 \\ Direvisi : 15 April 2021 \\ Disetujui : 29 Mei 2021 \\ Diterbitkan : 15 Juni 2021 \\ *Korespondensi Penulis : \\ yulibahriah@yahoo.co.id
}

\begin{abstract}
A B S T R A K
Data Kementrian Kesehatan Republik Indonesia didapatkan kejadian Kekurangan Energi Kronik (KEK) di Indonesia masih cukup tinggi. Salah satu penyebab terjadinya KEK adalah kurangnya asupan energi yang berasal dari zat gizi makro (karbohidrat, protein dan lemak) maupun zat gizi mikro terutama vitamin $\mathrm{A}$, vitamin $\mathrm{D}$, asam folat, zat besi, seng, kalsium dan iodium, kurangnya konsumsi tablet Fe serta kejadian anemia. Tujuan penelitian ini adalah untuk mengetahui hubungan kepatuhan mengkonsumsi tablet $\mathrm{Fe}$ dan anemia terhadap Kekurangan Energi Kronik (KEK) pada ibu hamil. Desain penelitian ini adalah menggunakan metode studi literatur. Sumber data dalam penelitian ini menggunakan data sekunder yang didapat dengan melakukan studi literatur dari jurnal-jurnal yang sesuai dengan topik penelitian dari tahun 2010-2020 sebanyak 10 jurnal. Berdasarkan hasil literatur review yang dilakukan oleh penulis, dapat disimpulkan bahwa menyatakan ada hubungan yang bermakna antara kepatuhan mengkonsumsi tablet Fe dan anemia dengan Kekurangan Energi Kronik (KEK) pada ibu hamil. Berdasarkan hasil literatur review diketahui bahwa faktor yang dominan menjadi penyebab Kekurangan Energi Kronik (KEK) pada ibu hamil adalah kejadian anemia. Saran bagi petugas kesehatan diharapkan adanya penyuluhan kesehatan kepada ibu hamil akan pentingnya mengonsumsi tablet fe dalam mencegah terjadinya anemia serta melakukan pengamatan terhadap status gizi ibu hamil sehingga dapat dihindari terjadinya kurang energi kronis pada ibu hamil sedini mungkin.
\end{abstract}

Kata Kunci : Tablet Fe, Anemia, Kekurangan Energi Kronik (KEK), Pada Ibu Hamil

\begin{abstract}
The nutritional status of pregnant women is one indicator in measuring the nutritional status of the community. If the nutritional input for pregnant women from food is not balanced with the body's needs, there will be a deficiency of nutrients. Iron and folic acid are needed by pregnant women to prevent anemia and maintain optimal fetal growth. Pregnant women with Chronic Energy Deficiency (KEK) tend to have more anemia than anemia. This is caused by the pattern of consumption and absorption of food that is not balanced during pregnancy. The purpose of this study was to determine the relationship of adherence to consume Fe tablets and anemia to Chronic Energy Deficiency (KEK) in pregnant women. The design of this study was to use the literature study method.Based on the results of the literature review conducted by the authors, it can be concluded that most of the literature (11 journals) states there is a significant relationship between adherence to consume
\end{abstract}


Fe tablets and anemia with Chronic Energy Deficiency (KEK) in pregnant women. Whereas 2 other literature states there is no significant relationship between chronic lack of energy with the incidence of anemia in pregnant women.Based on the results of the literature review known that the dominant factor causing Chronic Energy Deficiency (KEK) in pregnant women is the incidence of anemia.Suggestions for health workers are expected the existence of health education to pregnant women on the importance of consuming Fe tablets in preventing anemia and observing the nutritional status of pregnant women so that it can be avoided the occurrence of chronic lack of energy in pregnant women as early as possible.

Keywords : Fe tablets, anemia, chronic energy deficiency (KEK), in pregnant women

\section{PENDAHULUAN}

Status gizi ibu hamil merupakan salah satu indikator dalam mengukur status gizi masyarakat. Jika masukan gizi untuk ibu hamil dari makanan tidak seimbang dengan kebutuhan tubuh maka akan terjadi defisiensi zat gizi. Kekurangan zat gizi dan rendahnya derajat kesehatan ibu hamil masih sangat rawan, hal ini ditandai masih tingginya Angka Kematian Ibu (AKI) yang disebabkan oleh perdarahan karena anemia gizi dan Kekurangan Energi Kronik (KEK) selama masa kehamilan (Yuliastuti, 2018).

\section{United Nations Children's Fund} (UNICEF) mengungkapkan bahwa lebih dari 290.000 perempuan meninggal akibat komplikasi kehamilan dan kelahiran pada tahun 2017 dan terdapat 2,8 juta ibu hamil dan bayi baru lahir yang meninggal setiap tahun, atau 1 kematian setiap 11 detik. Angka kematian ibu di Afrika Sub-Sahara hampir 50 kali lebih tinggi dan bayi 10 kali lebih berisiko mengalami kematian dalam bulan pertama kehidupan dibandingkan penduduk di negara berpendapatan tinggi. Setiap 1 dari 37 perempuan di Afrika Sub-Sahara menghadapi risiko sepanjang hidup terjadi kematian saat kehamilan atau kelahiran. Jika dibandingkan, risiko sepanjang hidup yang sama yang dihadapi perempuan di Eropa adalah 1 dalam
6500 orang. Kawasan Afrika Sub-Sahara dan Asia Selatan menyumbang sekitar $80 \%$ angka kematian ibu dan anak secara global (Unicef, 2019).

Berdasarkan data yang didapat dari Kementrian Kesehatan Republik Indonesia (2018), jumlah ibu hamil yang mengalami KEK sebesar $82,83 \%$. Provinsi dengan jumlah ibu hamil dengan KEK terbanyak terdapat pada Daerah Intimewa Aceh sebesar 99,50\% dan Provinsi dengan jumlah ibu hamil dengan KEK terendah terdapat pada Provinsi Kalimatan Barat sebesar 18,41\%. Sedangkan untuk Provinsi Sumatera Selatan jumlah ibu hamil yang mengalami KEK sebanyak $90,46 \%$. Sementara proporsi ibu hamil dengan tingkat kecukupan protein kurang dari $80 \%$ angka kecukupan protein (AKP) juga lebih tinggi di pedesaan dibandingkan dengan perkotaan yaitu sebesar $55,7 \%$ dibandingkan 49,6\%. (Kemenkes, 2018).

Berdasarkan data Dinas Kesehatan Kota Palembang menunjukkan bahwa data salah satu dari 10 jenis komplikasi kebidanan terbanyak di Kota Palembang tahun 2018 adalah komplikasi atau faktor resiko ibu hamil, ibu bersalin dan ibu nifas terbanyak adalah terkait masalah gizi yaitu ibu hamil KEK (LILA < 23,5 cm) sebanyak 1.595 orang dan ibu hamil anemia $(\mathrm{Hb}<11$ gr\%) sebanyak 1.336 orang. Kasus KEK terbanyak berada di Kecamatan Ilir Barat I sebanyak 170 kasus sedangkan kasus ibu hamil dengan KEK paling sedikit adalah Kecamatan Bukit Kecil 
sebanyak 33 kasus. Sedangkan untuk cakupan pemberian tablet Fe pada ibu hamil di Kota Palembang tahun 2018 sebesar 99,1\%. Cakupan tersebut sudah mencapai target Kota Palembang yaitu 96\% (Dinkes Kota Palembang, 2019).

Terdapat berbagai macam faktor penyebab KEK, salah satu penyebabnya adalah konsumsi makan yang tidak cukup mengandung energi dan protein atau adanya gangguan kesehatan. Selama kehamilan diperlukan tambahan energi ekstra sebesar 340-450 kalori setiap hari pada trimester II dan III. Oleh karena itu, kekurangan zat gizi tertentu dan dibiarkan berlarut larut saat hamil dapat menyebabkan ibu hamil yang sebelumnya tidak KEK tidak mustahil akan mengalami KEK dan yang sudah KEK justru akan menimbulkan bahaya yang lebih besar (Lestari, 2018).

Untuk mengatasi masalah Kekurangan Energi Kronik (KEK) pada ibu hamil pemerintah Depkes RI telah melaksanakan suatu program pemberian tablet zat besi pada ibu hamil di Puskesmas dan Posyandu dengan mendistribusikan tablet tambah darah, dimana 1 tablet berisi $200 \mathrm{mg}$ fero sulfat dan $0,25 \mathrm{mg}$ asam folat (setara dengan $60 \mathrm{mg}$ besi dan 0.25 $\mathrm{mg}$ asam folat). Setiap ibu hamil dianjurkan minum tablet tambah darah dengan dosis satu tablet setiap hari selama masa kehamilannya dan empat puluh hari setelah melahirkan (Dinkes Kota Palembang, 2018).

Kurangnya asupan energi yang berasal dari zat gizi makro (karbohidrat, protein dan lemak) maupun zat gizi mikro terutama vitamin $A$, vitamin $D$, asam folat, zat besi, seng, kalsium dan iodium serta zat gizi mikro lain pada wanita usia subur yang berkelanjutan (remaja sampai masa kehamilan), mengakibatkan terjadinya Kurang Energi Kronik (KEK) pada masa kehamilan, yang diawali dengan kejadian risiko KEK dan ditandai oleh rendahnya cadangan energi dalam jangka waktu cukup lama yang diukur dengan lingkar lengan atas (LILA). Ibu hamil dengan masalah gizi dan kesehatan berdampak terhadap kesehatan dan keselamatan ibu dan bayi serta kualitas bayi yang dilahirkan. Kondisi ibu hamil KEK berisiko menurunkan kekuatan otot yang membantu proses persalinan sehingga dapat mengakibatkan terjadinya kematian janin (keguguran), prematur, lahir cacat, bayi berat lahir rendah (BBLR) bahkan kematian bayi, ibu hamil KEK dapat mengganggu tumbuh kembang janin yaitu pertumbuhan fisik (stunting), otak dan metabolisme yang menyebabkan penyakit menular di usia dewasa (Kemenkes, 2018).

Zat besi dan asam folat sangat dibutuhkan oleh ibu hamil untuk mencegah terjadinya anemia dan menjaga pertumbuhan janin secara optimal. Kementerian Kesehatan menganjurkan agar ibu hamil mengonsumsi paling sedikit 90 pil zat besi selama kehamilannya. Sebanyak 73,8 persen ibu mengonsumsi $\geq 90$ tablet $\mathrm{Fe}$ dan asam folat selama masa kehamilan. Tingkat kepatuhan untuk konsumsi tablet $\mathrm{Fe}$ dan asam folat juga baik yaitu dikonsumsi setelah makan. Hal ini juga terbantu oleh pemberian $\mathrm{Fe}$ dan asam folat oleh tenaga kesehatan yang diberikan pada trimester III 45,2 persen. Angka Kecukupan Gizi (AKG) mineral Fe pada wanita usia subur (WUS) yaitu $26 \mathrm{mg}$ dan pada kondisi hamil trimester II kebutuhannya meningkat $9 \mathrm{mg}$ serta $13 \mathrm{mg}$ untuk trimester III. Hal ini terjadi karena selama trimester pertama kebutuhan akan zat besi minimal kemudian kecepatan absorbsinya meningkat sekitar 7 persen pada kehamilan 12 minggu hingga 66 persen pada 36 minggu (Kusumawati, 2016).

Ibu hamil yang Kekurangan Energi Kronik (KEK) cenderung lebih banyak mengalami anemia dibandingkan tidak terjadi anemia. ini disebabkan karena pola konsumsi dan absorbsi makanan yang tidak seimbang selama kehamilan. Nutrisi sangat mempengaruhi keadaan gizi seseorang. Jika ibu hamil selama kehamilannya tidak mengkonsumsi gizi seimbang, baik 
makronutrien maupun mikronutrien maka ibu hamil beresiko mengalami gangguan gizi atau dapat terjadinya kekurangan energi kronis yang dapat mengakibatkan terjadinya anemia (Fidyah, 2017).

Berdasarkan hasil penelitian Suhaeti (2018), yang berjudul faktor-faktor yang berhubungan dengan status gizi ibu hamil di Wilayah Kerja Puskesmas Lalundu Kabupaten Donggala. Hasil uji statistik Chi-Square Test menunjukkan nilai $\mathrm{p}=0.001<0.05$ yang berarti ada hubungan yang bermakna antara anemia dengan status gizi ibu hamil di Wilayah Kerja Puskesmas Lalundu Kabupaten Donggala.

Berdasarkan hasil penelitian Lestari (2018) yang berjudul hubungan kepatuhan mengkonsumsi tablet Fe (Zat Besi) dan asupan makanan dengan kejadian Kekurangan Energi Kronis (KEK) pada ibu hamil di Kota Mataram. Hasil uji statistik bivariat dengan menggunakan chi squre menunjukkan bahwa ada hubungan asupan makanan $(0.000<0.05)$ dan kepatuhan mengkonsumsi tablet Fe $(0,000$ $<0,05)$ dengan kejadian Kekurangan Energi Kronis (KEK) pada ibu hamil di Kota Mataram.

Dari data diatas maka peneliti menggunakan studi pustaka untuk mengetahui hubungan kepatuhan mengkonsumsi tablet Fe dan anemia terhadap Kekurangan Energi Kronik (KEK) pada ibu hamil. Study pustaka adalah study yang tujuannya untuk memperoleh dukungan teoritis terhadap masalah peneliti yang dipilih, maka peneliti perlu banyak membaca buku, baik berupa teks (teori) maupun hasil penelitian orang lain, majalah, jurnal, dan sebagainya. (Notoatmodjo, 2012).

$$
\text { Dalam melakukan penelitian }
$$

kepustakaan ada beberapa teknik yang digunakan antara lain, mengupas (criticize), membandingkan (compare), meringkas (summarize), mengumpulkan (synthesize), dan bertentangan (contrast). Dalam penelitian dipergunakan metode compare dengan judul hubungan kepatuhan mengkonsumsi tablet Fe dan anemia terhadap Kekurangan Energi Kronik (KEK) pada ibu hamil (Studi Pustaka Dengan Metode Compare).

\section{METODE PENELITIAN}

\section{Fokus Penelitian}

Fokus penelitian ini mengunakan metode compare atau membandingkan, dimana peneliti mengumpulkan teori-teori dari buku-buku, jurnal dan skripsi penelitian terdahulu tentang kepatuhan mengkonsumsi tablet Fe dan anemia terhadap Kekurangan Energi Kronik (KEK) pada ibu hamil, kemudian di bandingkan sehingga membentuk atau menghasilkan pendapat baru mengenai kepatuhan mengkonsumsi tablet $\mathrm{Fe}$ dan anemia terhadap Kekurangan Energi Kronik (KEK) pada ibu hamil.

\section{Cara Pengumpulan Data}

Data yang dipakai atau digunakan dalam penelitian ini menggunakan data sekunder dimana teori-teori yang diambil dari berbagai buku yang berkaitan dengan kepatuhan mengkonsumsi tablet $\mathrm{Fe}$ dan anemia terhadap Kekurangan Energi Kronik (KEK) pada ibu hamil.

Penelitian ini penulis hanya menggunakan membandingkan (Compare) dari teori-teori yang ada sebelumnya mengenai kepatuhan mengkonsumsi tablet $\mathrm{Fe}$ dan anemia terhadap Kekurangan Energi Kronik (KEK) pada ibu hamil.

\section{Situasi Sosial}

Dalam penelitian ini, menggunakan studi pustaka dimana tujuannya untuk memperoleh dukungan teoritis terhadap masalah penelitian yang dipilih, maka peneliti perlu banyak membaca buku, baik berupa teks (teori), maupun hasil penelitian orang lain, majalah, jurnal, dan sebagainya. 


\section{Tekhnik Analisis}

\begin{tabular}{ccc}
\multicolumn{2}{c}{ Penelitian ini hanya } & mengunakan \\
teknik & membandingkan & (Compare) \\
menjelaskan & mengenai & kepatuhan
\end{tabular} mengkonsumsi tablet Fe dan anemia terhadap Kekurangan Energi Kronik (KEK) pada ibu hamil dan berdasarkan teori-teori maupun dari jurnal atau penelitian-penelitian yang sudah dilakukan sebelumnya kemudian diringkas sehingga membentuk atau menghasilkan pendapat baru mengenai hubungan kepatuhan mengkonsumsi tablet Fe dan anemia terhadap Kekurangan Energi Kronik (KEK) pada ibu hamil.

\section{HASIL PENELITIAN}

Menurut penelitian yang dieliti oleh Mahirawati (2012) yang berjudul faktor-faktor yang berhubungan dengan Kekurangan Energi Kronis (KEK) Pada Ibu Hamil Di Kecamatan Kamoning Dan Tambelangan, Kabupaten Sampang, Jawa Timur. Faktor ibu yang berhubungan dengan kejadian KEK adalah umur menikah dan umur kehamilan pertama yang terlalu muda ( $<20$ tahun), paritas dan kadar haemoglobin $(\mathrm{Hb})$. Ditemukan sebanyak 70,6\% ibu hamil KEK yang menderita anemia walaupun sebanyak 66,7\% ibu hamil KEK sudah mengonsumsi pil besi (Fe) setiap hari. Sebanyak $98,1 \%$ ibu hamil mengonsumsi pil besi $(\mathrm{Fe})$ dalam sehari, namun persentase terbanyak pada ibu hamil yang tidak KEK yaitu sebesar $66,7 \%$. Dalam penelitian ini dijelaskan bahwa ibu hamil yang tidak mengonsumsi pil besi secara teratur lebih banyak yang mengalami KEK yaitu 33,3\% sedangkan pada ibu hamil yang tidak KEK hanya ada $1,0 \%$. Ada hubungan bermakna antara konsumsi pil besi dalam sehari dengan kejadian KEK pada ibu hamil.

Menurut penelitian yang dieliti oleh Ratnawati (2013) yang berjudul Kekurangan Energi Kronis dengan Kejadian Anemia Pada Ibu Hamil di BPS Istiqomah Surabaya. Dari 107 Ibu hamil yang memeriksakan kehamilannya di BPS Istiqomah Surabaya sebagian besar dari ibu hamil tersebut $(63,55 \%)$ mengalami Kurang Energi Kronik. Hampir setengahnya dari ibu hamil $(36,50 \%)$ yang tidak mengalami KEK dan sebagian besar ibu hamil $(58,88 \%)$ tidak mengalami anemia, tetapi ditemukan hampir setengahnya ibu hamil $(41,12 \%)$ yang mengalami anemia. Berdasarkan hasil analisis statistik dengan rumus uji Chi Square, didapatkan hitung $(7,12)>$ tabel $(3,84)$, maka H1 diterima H0 ditolak artinya terdapat hubungan antara kekurangan energi kronis dengan kejadian anemia pada ibu hamil.

Menurut penelitian yang dieliti oleh Mardiatun (2013) yang berjudul Hubungan Riwayat Ante Natal Care (ANC) dan Tingkat Konsumsi Fe (Zat Besi) Dengan Kejadian KEK Ibu Hamil Di Provinsi Nusa Tenggara Barat Dan Di Daerah Istimewa Jogjakarta (Analisis Lanjut Data Riset Kesehatan Dasar 2013). Hasil uji statistik Chi Square di NTB didapatkan nilai $\mathrm{p}(0,000)<0,05$ sehingga dapat disimpulkan bahwa terdapat hubungan antara tingkat konsumsi $\mathrm{Fe}$ dengan risiko kejadian KEK di NTB dengan nilai OR 0,901. Hasil uji statistik Chi Square DIJ didapatkan nilai p $(0,000)<0,05$ sehingga dapat disimpulkan bahwa terdapat hubungan antara tingkat konsumsi $\mathrm{Fe}$ dengan risiko kejadian KEK di DIJ dengan nilai OR 23,392. Dalam penelitian ini juga dijelaskan bahwa kejadian KEK pada ibu hamil tidak saja dipengaruhi oleh tingkat konsumsi Fe saja melainkan juga riwayat status gizi sebelum hamil, adanya riwayat penyakit kronis dan lain-lain karena biasanya pada ibu hamil terjadi peningkatan nafsu makan sehingga dapat mencegah terjadinya KEK tapi tidak menjamin bisa mencegah terjadinya anemia walaupun mengonsumsi Fe kecuali ibu hamil tersebut tingkat konsumsi protein hewani maupun vitamin $\mathrm{C}$ nya memadai sehingga dapat membantu penyerapan Fe di dalam tubuh.

Menurut penelitian yang dieliti oleh Aminin (2014) yang berjudul Pengaruh Kekurangan Energi Kronis (KEK) Dengan 
Kejadian Anemia Pada Ibu Hamil di Posyandu Gelatik Kota Tanjungpinang. Populasi dalam penelitian ini adalah seluruh ibu hamil yang memeriksakan kehamilannya di Puskesmas Kota Tanjungpinang pada bulan Juni tahun 2014 dengan jumlah sampel berjumlah $31 \mathrm{ibu}$ hamil. Hasil uji statistik didapatkan ada Pengaruh Kekurangan Energy Kronis (KEK) terhadap kejadan anemia pada ibu hamil di Puskesmas Kota Tanjungpinang dengan $\mathrm{p}$ value $=0.002 \leq 0.05$. Hasil penelitian ini menunjukkan bahwa ibu hamil dengan KEK lebih banyak yang anemia dibandingkan ibu hamil yang tidak KEK. Hal ini disebabkan karena pola konsumsi dan absorbsi makanan yang tidak seimbang selama kehamilan. Nutrisi sangat mempengaruhi keadaan gizi seseorang. Jika ibu hamil selama kehamilannya tidak mengkonsumsi gizi seimbang, baik makronutrien maupun mikronutrien maka ibu hamil beresiko mengalami gangguan gizi atau dapat terjadinya kekurangan energi kronis yang dapat mengakibatkan terjadinya anemia.

$$
\text { Menurut hasil penelitian }
$$

Sukmaningtyas (2015) yang berjudul hubungan antara tingkat pengetahuan dan status gizi ibu hamil dengan kejadian anemia di Puskesmas Gatak Kabupaten Sukoharjo. Hasil penelitian menunjukkan bahwa pada variabel status gizi, responden yang memiliki status gizi kurang sebanyak 15 orang $(50 \%)$ pada kelompok kasus dan 5 orang $(16,7 \%)$ pada kelompok kontrol. Hasil statistik menunjukkan bahwa ada hubungan antara status gizi $(p=0,006)$ dengan kejadian anemia di Puskesmas Gatak Kabupaten Sukoharjo.

Menurut penelitian yang dieliti oleh Kusumawati (2016) yang berjudul hubungan asupan makanan, suplementasi Fe dan asam folat dengan kadar hemoglobin pada ibu hamil riwayat kurang energi kronis dan anemia saat menyusui. Subjek pada penelitian ini adalah 42 ibu menyusui bayi usia 6 bulan sampai 1 tahun yang memiliki riwayat KEK dan anemia selama masa kehamilan trimester III. Hasil menunjukkan bahwa asupan energi, lemak, karbohidrat, zat besi dan asam folat pada ibu menyusui termasuk kategori defisit $(<70 \%$ $\mathrm{AKG})$. Asupan makanan dan status gizi ibu menyusui berhubungan negatif terhadap kadar hemoglobin saat menyusui $(\mathrm{p}=0,016)$. Suplementasi Fe dan asam folat pada ibu hamil riwayat KEK dan anemia berhubungan secara signifikan terhadap kadar hemoglobin saat menyusui $(\mathrm{p}=0,016)$. Dapat disimpulkan bahwa suplementasi Fe dan asam folat pada ibu hamil KEK dan anemia berpeluang menaikkan 0,720 g/dL kadar hemoglobin ibu saat menyusui.

Menurut penelitian yang dieliti oleh Suhaeti (2018), yang berjudul faktor-faktor yang berhubungan dengan status gizi ibu hamil di Wilayah Kerja Puskesmas Lalundu Kabupaten Donggala. Sampel dalam penelitian ini yaitu semua ibu hamil yang berkunjung di Puskesmas Lalundu Kabupaten Donggala yang berjumlah 54 responden yang mewakili jumlah dari populasi. Hasil analisis univariat menunjukkan bahwa, responden yang tidak anemia lebih banyak dibandingkan dengan yang anemia. Dimana responden dengan tidak anemia sebanyak 32 orang (59.3\%) dan responden dengan anemia sebanyak 22 orang $(40.7 \%)$ dan distribusi menurut status gizi ibu hamil menunjukkan bahwa sebagian besar responden dengan status gizi "normal" sebanyak 35 orang $(64.8 \%)$ dan responden dengan status gizi "tidak normal" sebanyak 19 orang (35.2\%). Hasil uji statistik Chi-Square Test menunjukkan nilai $\mathrm{p}=0.001$ $<0.05$ yang berarti ada hubungan yang bermakna antara anemia dengan status gizi ibu hamil di Wilayah Kerja Puskesmas Lalundu Kabupaten Donggala.

Menurut penelitian yang dieliti oleh Lestari (2018) yang berjudul hubungan kepatuhan mengkonsumsi tablet Fe (Zat Besi) dan asupan makanan dengan kejadian Kekurangan Energi Kronis (KEK) pada ibu hamil di Kota Mataram. Hasil penelitian didapatkan responden yang mengalami KEK 
sebanyak 36 responden $(9,0 \%)$ sedangkan responden yang tidak mengalami KEK sebanyak 363 orang $(91,0 \%)$. Responden yang kepatuhannya tinggi sebanyak 179 orang $(44,9 \%)$ dan responden yang kepatuhannya rendah sebanyak 220 orang $(55,1 \%)$. Responden yang asupan makanannya sesuai sebanyak 237 orang $(40,6 \%)$ dan responden yang asupan makanannya tidak sesuai sebanyak 162 orang $(40,6 \%)$. Hasil uji statistik bivariat dengan menggunakan chi squre menunjukkan bahwa ada hubungan asupan makanan $(0.000<0.05)$ dan kepatuhan mengkonsumsi tablet $\mathrm{Fe}(0,000<0,05)$ dengan kejadian Kekurangan Energi Kronis (KEK) pada ibu hamil di Kota Mataram. Dalam penelitian ini jumlah persentasi ibu yang mengalami kurang energi protein lebih cenderung tidak patuh dalam mengkonsumsi tablet Fe.

Menurut penelitian yang diteliti oleh Erlinawati (2018) yang berjudul Hubungan Anemia Ibu Hamil Dengan Kejadian Kekurangan Energi Kronis (KEK) Di Wilayah Kerja Puskesmas Tapung Perawatan. Populasi dalam penelitian ini adalah semua ibu hamil di Wilayah Kerja Puskesmas Tapung dengan jumlah sampel sebanyak 88 orang. Hasil penelitian didapatkan dari $22(25 \%)$ ibu hamil yang mengalami anemia mayoritas mengalami KEK sebanyak 17 orang (42,5\%), sedangkan dari 66 ibu hamil yang tidak anemia sebagian besar tidak mengalami KEK sebanyak 43 ibu hamil $(89,6 \%)$. Berdasarkan uji statistik di peroleh $\mathrm{p}$ value $(0,001<\alpha)$ artinya ada hubungan anemia ibu hamil dengan kejadian kekurangan energi kronis. Dalam penelitian ini dijelaskan bahwa anemia dapat mempengaruhi kejadian KEK apabila kadar $\mathrm{Hb}$ dibawah batas ambang terus menerus maka peluang terjadi anemia semakin besar.

Berdasarkan hasil penelitian Helliyana (2018) yang berjudul Hubungan Pengetahuan Gizi Dan Kurang Energi Kronis (KEK) dengan Anemia Pada Ibu Hamil Di Puskesmas Muara Satu Kota Lhokseumawe Tahun 2018.
Hasil penelitian menunjukkan bahwa $60 \%$ pengetahuan gizi kurang, 63,3\% mengalami KEK dan terdapat $54,4 \%$ anemia pada ibu hamil. Hasil analisis chi-square menunjukkan ada hubungan KEK $(\mathrm{p}=0,000)$ dengan anemia pada ibu hamil di Puskesmas Muara Satu Kota Lhokseumawe.

\section{PEMBAHASAN}

Berdasarkan hasil literatur review penelitian terhadap 10 jurnal yaitu Mahirawati (2012), Ratnawati (2013), Mardiatun (2013), Aminin (2014), Sukmaningtyas (2015), Kusumawati (2016), Suhaeti (2018), Lestari (2018), Erlinawati (2018), dan Helliyana (2018), diketahui masih banyak ibu hamil yang mengalami kekurangan energi kronik (KEK) hal ini disebabkan karena banyak ibu hamil yang tidak patuh dalam mengkonsumsi tablet Fe dengan alasan mual selain itu banyak ibu hamil mengalami anemia ringan disebabkan karena kurangnya asupan makanan yang mengandung zat besi seperti sayuran hijau dan makanan yang mengandung protein seperti ikan, telur dan daging.

Hasil penelitian dari 10 jurnal tersebut semuanya juga menjelaskan bahwa kepatuhan mengkonsumsi tablet $\mathrm{Fe}$ dan anemia berhubungan dengan kejadian Kekurangan Energi Kronik (KEK) pada ibu hami. Ibu yang tidak patuh mengkonsumsi tablet $\mathrm{Fe}$ akan cenderung mengalami kekurangan zat besi dan apabila pasokan zat besi didalam tubuh kurang maka ibu hamil beresiko mengalami anemia dan dapat berakibat terjadinya anemia yang berdampak buruk pada ibu dan janin. Selain itu ibu yang mengalami anemia juga dapat dipengaruhi oleh asupan gizi. Jika asupan gizi untuk ibu hamil dari makanan tidak seimbang dengan kebutuhan tubuh maka akan terjadi defisiensi zat gizi dan berdampak pada Kekurangan Energi Kronik (KEK).

Hal ini sesuai dengan pernyataan Mahirawati (2012), dijelaskan bahwa ibu hamil yang tidak mengonsumsi pil besi secara 
teratur lebih banyak yang mengalami KEK dan didapatkan ada hubungan bermakna antara konsumsi pil besi dalam sehari dengan kejadian KEK pada ibu hamil. Ibu hamil yang menderita KEK dan anemia mempunyai risiko kesakitan yang lebih besar terutama pada saat kehamilan trimester 3 dibandingkan dengan ibu hamil yang tidak KEK dan tidak anemia. Selain itu, ibu hamil KEK dan anemia juga lebih berisiko untuk melahirkan bayi dengan berat bayi lahir rendah (BBLR), kematian saat persalinan, perdarahan, juga kondisi fisik yang lemah setelah proses persalinan karena lebih mudah mengalami gangguan kesehatan. Selama masa kehamilan kebutuhan zat gizi yang diperlukan untuk metabolisme tubuh baik pada ibu dan janin dalam kandungan meningkat. Oleh karena itu pada masa kehamilan asupan zat gizi yang diperlukan juga meningkat, untuk pertumbuhan dan perkembangan janin juga pertambahan besarnya organ kandungan, perubahan komposisi dan metabolisme tubuh ibu dan janin. Ibu hamil yang mengalami kekurangan asupan zat gizi dan berstatus gizi buruk maka mempunyai peluang besar untuk melahirkan bayi dengan berat badan lahir rendah (BBLR).

Hal serupa dinyatakan Ratnawati (2013) menjelaskan bahwa sebagian besar anemia yang terjadi pada ibu hamil disebabkan karena kekurangan zat besi $(\mathrm{Fe})$ yang disebut anemia kekurangan zat besi atau anemia zat besi. Anemia juga merupakan keadaan menurunnya jumlah sel darah merah atau penurunan konsentrasi hemoglobin di dalam sirkulasi darah. Perubahan fisiologis alami yang terjadi selama kehamilan akan mempengaruhi jumlah sel darah normal pada kehamilan.

Hal yang sama dinyatakan Mardiatun (2013), dijelaskan bahwa kejadian KEK pada ibu hamil tidak saja dipengaruhi oleh tingkat konsumsi $\mathrm{Fe}$ saja melainkan juga riwayat status gizi sebelum hamil, adanya riwayat penyakit kronis dan lain-lain karena biasanya pada ibu hamil terjadi peningkatan nafsu makan sehingga dapat mencegah terjadinya KEK tapi tidak menjamin bisa mencegah terjadinya anemia walaupun mengkonsumsi Fe kecuali ibu hamil tersebut tingkat konsumsi protein hewani maupun vitamin $\mathrm{C}$ nya memadai sehingga dapat membantu penyerapan $\mathrm{Fe}$ di dalam tubuh. Kurang Energi Kronis (KEK) pada kehamilan merupakan masalah gizi di Indonesia. Kontribusi dan terjadinya KEK pada ibu hamil akan mempengaruhi tumbuh kembang janin antara lain dapat meningkatkan risiko terjadinya berat bayi lahir rendah (BBLR). Ibu hamil dengan KEK memiliki risiko kesakitan yang lebih besar, terutama pada trimester III kehamilan sehingga dapat mengakibatkan kelahiran BBLR. Anemia sering terjadi akibat defisiensi zat besi karena pada ibu hamil terjadi peningkatan kebutuhan zat besi dua kali lipat akibat peningkatan volume darah tanpa ekspansi volume plasma, untuk memenuhi kebutuhan ibu (mencegah kehilangan darah pada saat melahirkan) dan pertumbuhan janin. Ironisnya, diestimasi di bawah 50\% ibu tidak mempunyai cadangan zat besi yang cukup selama kehamilannya, sehingga risiko defisiensi zat besi atau anemia meningkat bersama dengan kehamilan.

Begitu juga dengan pernyataan Aminim (2014), dijelaskan bahwa ibu hamil yang KEK cenderung lebih banyak mengalami anemia dibandingkan tidak terjadi anemia. Ini disebabkan karena pola konsumsi dan absorbsi makanan yang tidak seimbang selama kehamilan. Nutrisi sangat mempengaruhi keadaan gizi seseorang. Jika ibu hamil selama kehamilannya tidak mengkonsumsi gizi seimbang, baik makronutrien maupun mikronutrien maka ibu hamil beresiko mengalami gangguan gizi atau dapat terjadinya kekurangan energi kronis yang dapat mengakibatkan terjadinya anemia. Ibu hamil yang tidak KEK, cenderung lebih kecil tidak mengalami anemia dibandingkan mengalami anemia. Ibu hamil yang tidak KEK biasanya lebih menjaga pasokan nutrisi yang di 
konsumsi selama kehamilannya dengan mengkonsumsi makanan yang mengandung gizi seimbang, baik makronutrien maupun mikronutrien, disertai konsumsi Vitamin $\mathrm{C}$ sehingga ibu hamil kemungkinan kecil mengalami anemia. Namun pada trimester I biasanya ibu hamil mengalami mual dan muntah, yang apabila mengkonsumsi vitamin $\mathrm{C}$ dapat meningkatkan asam lambung oleh karena itu untuk membantu penyerapan zat besi disertai dengan konsumsi air putih. Jika ibu hamil yang tidak KEK mengalami anemia, kemungkinan disebabkan cara menjaga zat besi didalam makanan tidak disertai dengan konsumsi makanan ataupun konsumsi air putih yang dapat membantu penyerapan zat besi, karena apabila konsumsi kafein dapat menghambat penyerapan zat besi.

Sedangkan menurut Sukmaningtyas (2015), juga memberikan pernyataan yang sama bahwa secara teori terdapat hubungan erat antara anemia dengan KEK, karena KEK bisa juga menjadi kurang protein karena konsumsi protein akan digunakan sebagai sumber energi. Anemia mengakibatkan pasokan oksigen didalam tubuh menjadi rendah sehingga akibatnya tidak cukup energi yang dapat digunakan oleh tubuh. Status gizi ibu hamil dapat menyebabkan terjadinya anemia, hal ini dapat disebabkan karena konsumsi asupan makanan yang banyak mengandung zat besi kurang, bisa juga karena faktor ekonomi, infeksi maupun konsumsi makanan atau minuman penghambat penyerapan zat besi. Meskipun tingkat pengetahuan rata-rata ibu hamil di wilayah kerja Puskesmas Gatak tinggi, namun hal tersebut belum menjamin status gizinya juga baik. Meskipun pengetahuan tinggi tapi tidak mengaplikasikan pengetahuan yang mereka ketahui, maka bisa juga

Hal serupa dinyatakan Kusumawati (2016), dijelaskan bahwa asupan gizi, suplemen fe dan asam folat berpengaruh terHadap kejadian KEK dan anemia ibu hamil. Ketidakmampuan dalam memenuhi kebutuhan intake zat gizi pada masa kehamilan akan menyebabkan kurang energi kronis (KEK) dan anemia serta meningkatkan risiko kesakitan bahkan kematian pada ibu hamil. Supmentasi Fe dan asam folat mayoritas dikonsumsi $>90$ tablet sesuai program tablet tambah darah untuk ibu selama masa kehamilan yang dianjurkan oleh pemerintah. Status gizi ibu saat menyusui berdasarkan rerata IMT (20,2 $\mathrm{kg} / \mathrm{m} 2$ ) menunjukkan dalam kategori normal, sedangkan berdasarkan LILA $(22,7 \mathrm{~cm})$ dalam kategori KEK. Zat besi dan asam folat sangat dibutuhkan oleh ibu hamil untuk mencegah terjadinya anemia dan menjaga pertumbuhan janin secara optimal. Kementerian Kesehatan menganjurkan agar ibu hamil mengonsumsi paling sedikit 90 pil zat besi selama kehamilannya.

Selain itu dikatakan menurut Suhaeti (2018) bahwa ada status gizi ibu hamil merupakan salah satu indikator dalam mengukur status gizi masyarakat. Jika asupan gizi untuk ibu hamil dari makanan tidak seimbang dengan kebutuhan tubuh maka akan terjadi defisiensi zat gizi. Kehamilan menyebabkan meningkatnya metabolisme energi. Karena itu, kebutuhan energi dan zat gizi lainnya meningkat selama kehamilan. Peningkatan energi dan zat gizi tersebut diperlukan untuk pertumbuhan dan perkembangan janin, pertambahan besarnya organ kandungan, serta perubahan komposisi dan metabolisme tubuh ibu. Sehingga kekurangan zat gizi tertentu yang diperlukan saat hamil dapat menyebabkan janin tumbuh tidak sempurna. Status gizi bu hamil akan berpengaruh terhadap ibu maupun janin. LILA menunjukkan status nutrisi ibu hamil. LILA < $23,5 \mathrm{~cm}$ menunjukkan status nutrisi ibu hamil kurang dan harus mendapatkan penanganan agar tidak terjadi komplikasi pada janin. Gizi kurang pada ibu hamil dapat menyebabkan resiko dan komplikasi pada ibu, seperti anemia, perdarahan dan berat badan ibu tidak bertambah secara normal serta terkena penyakit infeksi. Ibu yang sejak awal 
mengalami KEK (kurang Energi kronik) akan lebih beresiko melahirkan bayi dengan berat badan lahir rendah (BBLR) yaitu berat badan bayi $<2500$ gr.

Selain itu menurut Lestari (2018), Kurang Energi Kronis (KEK) pada ibu hamil berdampak terhadap ibu, janin yang dikandung dan bayi yang akan dilahirkan. KEK mempengaruhi pertumbuhan janin, risiko kematian neonatal, risiko terjadinya stunting dan Berat badan lahir rendah (BBLR). Kekurangan Energi Kronis(KEK) akan memberikan dampak pada janin, ibu dan bayi. Dampak bagi ibu antara lain anemia, perdarahan, berat badan ibu tidak bertambah secara normal, dan terkena penyakit infeksi, sedangkan dampak pada pada janin yaitu dapat mengakibatkan terjadi kematian janin (keguguran) pada trimester I, dapat mengganggu tumbuh kembang janin pada trimester II dan dapat menyebabkan terjadinya persalinan Iprematur pada trimester III

Sedangkan hal serupa menurut Erlinawati (2018), dijelaskan bahwa anemia dapat mempengaruhi kejadian KEK apabila kadar $\mathrm{Hb}$ dibawah batas ambang terus menerus maka peluang terjadi anemia semakin besar. KEK pada ibu hamil dapat mempengaruhi proses pertumbuhan janin, dan dapat menimbulkan abortus, kematian neonatal, cacat bawaan, anemia pada bayi, asfiksia intrapartum dan bayi dengan Berat Badan Lahir Rendah (BBLR) yang mempunyai risiko kematian, serta gangguan pertumbuhan dan perkembangan anak. Zat besi bagi ibu hamil sangat penting untuk pembentukan dan mempertahankan sel darah merah. Kecukupan sel darah merah akan menjamin sirkulasi oksigen dan metabolisme zat-zat gizi yang dibutuhkan ibu hamil. Selain itu asupan zat besi sejak awal kehamilan cukup baik, maka janin akan menggunakannya untuk kebutuhan tumbuh kembangnya. Sehingga kekurangan zat besi sebelum hamil bila tidak diatasi akan mengakibatkan ibu hamil menderita anemia, janin dan ibu mudah terkena infeksi dan keguguran

Hal yang sama dinyatakan Helliyana (2018), bahwa anemia pada ibu hamil berpengaruh besar terhadap kualitas sumber daya manusia di suatu negara.Anemia selama kehamilan dapat menimbulkan dampak negatif pada ibu dan janin yang dikandungnya. Ibu yang mengalami anemia akan cenderung memiliki daya tahan tubuh yang rendah sehingga sangat rentan terhadap penyakit infeksi. Anemia selama kehamilan juga dapat berdampak pada persalinan diantaranya lemahnya kontraksi rahim serta tenaga mengejan yang lemah. Tercukupinya kebutuhan zat besi yang diperlukan ibu hamil tidak terlepas dari perilaku dalam mengkonsumsi makanan yang mengandung zat besi. Hal ini berkaitan dengan tinggi rendahnya pengetahuan seseorang tentang zat besi. Seorang individu yang sering mengonsumsi sumber makanan yang mengandung zat besi akan tercukupi kebutuhan zat besinya sehingga akan dapat mencegah terjadinya anemia.

\section{Analisis Peneliti}

Berdasarkan hasil literatur review yang peneliti lakukan terhadap 10 jurnal diketahui sebagian besar menggunakan metode penelitian cross sectional yaitu sebesar $80 \%$ sedangkan yang menggunakan metode Exksperimen pre test dan post test dan deskriptif kuantitatif masing-masing hanya menyumbang $10 \%$..

Hasil literatur review terhadap 8 jurnal yang menggunakan metode cross sectional semuanya (100\%) menyatakan bahwa anemia ibu hamil dengan kejadian kekurangan energi kronis. Begitu juga dengan peneliian dengan metode eksperimen menyatakan bahwa Kekurangan Energi Kronik (KEK) pada ibu hamil berpengaruh terhadap kejadian anemia. Hal ini sesuai dengan teori yang menjelaskan bahwa KEK ibu hamil merupakan salah satu indikator dalam mengukur status gizi masyarakat. Jika asupan gizi untuk ibu hamil 
dari makanan tidak seimbang dengan kebutuhan tubuh maka akan terjadi defisiensi zat gizi. Kehamilan menyebabkan meningkatnya metabolisme energi. Karena itu, kebutuhan energi dan zat gizi lainnya meningkat selama kehamilan. Peningkatan energi dan zat gizi tersebut diperlukan untuk pertumbuhan dan perkembangan janin, pertambahan besarnya organ kandungan, serta perubahan komposisi dan metabolisme tubuh ibu. Sehingga kekurangan zat gizi tertentu yang diperlukan saat hamil dapat menyebabkan janin tumbuh tidak sempurna. Status gizi bu hamil akan berpengaruh terhadap ibu maupun janin. LILA menunjukkan status nutrisi ibu hamil. LILA < 23,5 cm menunjukkan status nutrisi ibu hamil kurang dan harus mendapatkan penanganan agar tidak terjadi komplikasi pada janin. Gizi kurang pada ibu hamil dapat menyebabkan resiko dan komplikasi pada ibu, seperti anemia, perdarahan dan berat badan ibu tidak bertambah secara normal serta terkena penyakit infeksi. Ibu yang sejak awal mengalami KEK (kurang Energi kronik) akan lebih beresiko melahirkan bayi dengan berat badan lahir rendah (BBLR) yaitu berat badan bayi $<2500$ gr.

Selain itu kejadian KEK pada ibu hamil tidak saja dipengaruhi oleh tingkat konsumsi $\mathrm{Fe}$ saja melainkan juga riwayat status gizi sebelum hamil, adanya riwayat penyakit kronis dan lain-lain karena biasanya pada ibu hamil terjadi peningkatan nafsu makan sehingga dapat mencegah terjadinya KEK tapi tidak menjamin bisa mencegah terjadinya anemia walaupun mengonsumsi Fe kecuali ibu hamil tersebut tingkat konsumsi protein hewani maupun vitamin $\mathrm{C}$ nya memadai sehingga dapat membantu penyerapan $\mathrm{Fe}$ di dalam tubuh.

Selain itu ibu hamil yang kurang mengkonsumsi makanan yang mengandung zat besi dalam kehamilan ataupun tidak mengkonsumsi tablet fe dapat berakibat terjadinya anemia yang berdampak buruk pada ibu dan janin. Pada ibu hamil trimester I biasanya terjadi hemodilusi (pengenceran darah), apabila pasokan zat besi didalam tubuh kurang maka ibu hamil beresiko mengalami anemia. pada ibu hamil trimester I yang belum mendapatkan tablet fe dikarenakan pada trimester I biasanya ibu mengalami mual dan muntah, yang mana pasokan zat besi hanya didapatkan dari makanan (hewani atau nabati). Oleh karena itu, Ibu hamil harus menjaga dan meningkatkan asupan nutrisi yang mengandung zat besi didalam makanan agar tidak mengalami resiko anemia dalam kehamilan.

\section{KESIMPULAN}

Setelah dilakukan penelitian dengan menggunakan metode compare atau pembanding ini yang mencari persamaan dan perbedaan dari sumber-sumber yang diteliti seperti buku dan jurnal dan didapatkan dari semua literatur yang didapat menyatakan ada hubungan antara kepatuhan mengkonsumsi tablet $\mathrm{Fe}$ dan anemia dengan Kekurangan Energi Kronik (KEK)pada ibu hamil. Berdasarkan hasil literatur review diketahui bahwa faktor yang dominan menjadi penyebab Kekurangan Energi Kronik (KEK) pada ibu hamil adalah kejadian anemia.

Hal ini sesuai dengan teori Winarsih. 2018. (Pengantar ilmu gizi dalam kebidana), menjelaskan bahwa dampak yang ditimbulkan dari Kekurangan Energi Kronik (KEK) pada ibu adalah dapat menyebabkan resiko dan komplikasi pada ibu antara lain: Anemia, perdarahan, berat badan ibu tidak bertambah secara normal dan terkena penyakit infeksi. Sehingga akan meningkatkan kematian ibu.

\section{DAFTAR PUSTAKA}

Aminin. 2015. Pengaruh Kekurangan Energi Kronis (Kek) Dengan Kejadian Anemia Pada Ibu Hamil.

Budiarni. 2018. Hubungan Pengetahuan, Sikap, Dan Motivasi Dengan 
Kepatuhan Konsumsi Tablet Besi Folat Pada Ibu Hamil.

Dinkes Kota Palembang. 2018. Profil Kesehatan Kota Palembang. http://www.dinkes.kotapalembang.go.i d, diakses 3 Februari 2020 .

Erlinawati. 2018. Hubungan Anemia Ibu Hamil Dengan Kejadian Kekurangan Energi Kronis (KEK) Di Wilayah Kerja Puskesmas Tapung Perawatan.

Fidyah. 2017. Faktor-Faktor Yang Berhubungan Dengan Kekurangan Energi Kronis Pada Ibu Hamil Di Wilayah Kerja Puskesmas Sungai Bilu Banjarmasin.

Fidyah. 2017. Hubungan Tingkat Pengetahuan Ibu Hamil Tentang Anemia Dengan Kepatuhan Konsumsi Tablet Fe Di Wilayah Kerja Puskesmas Masaran I Sragen.

Kemenkes. 2018. Profil Kesehatan Republik Indonesia. http://www.kemenkes. go.id, diakses 20 Januari 2020.

Kusumawardani. 2012. Pengaruh Penyuluhan Kesehatan Terhadap Tingkat Pengetahuan, Sikap Dan Praktik Ibu Dalam Pencegahan Demam Berdarah Dengue Pada Anak. Jurnal fakultas kedokteran Universitas Diponogoro.

Kusumawati. 2016. Hubungan Asupan Makanan, Suplementasi Fe Dan Asam Folat Dengan Kadar Hemoglobin Pada Ibu Hamil Riwayat Kurang Energi Kronis Dan Anemia Saat Menyusui.

Lestari. 2018. Hubungan kepatuhan mengkonsumsi tablet Fe (Zat Besi) dan asupan makanan dengan kejadian Kekurangan Energi Kronis (KEK) pada ibu hamil di Kota Mataram.
Mahfudhoh. 2015. Faktor Yang Mempengaruhi Kepatuhan Penulisan Resep Sesuai Formularium.

Mahirawati . 2012. Faktor-faktor yang berhubungan dengan Kekurangan Energi Kronis (KEK) Pada Ibu Hamil Di Kecamatan Kamoning Dan Tambelangan, Kabupaten Sampang, Jawa Timur.

Mahirawati. 2012. Faktor-faktor yang berhubungan dengan Kekurangan Energi Kronis (KEK) Pada Ibu Hamil Di Kecamatan Kamoning Dan Tambelangan, Kabupaten Sampang, Jawa Timur.

Mardiatun. 2013. Hubungan Riwayat Ante Natal Care (ANC) dan Tingkat Konsumsi Fe (Zat Besi) Dengan Kejadian KEK Ibu Hamil Di Provinsi Nusa Tenggara Barat Dan Di Daerah Istimewa Jogjakarta (Analisis Lanjut Data Riset Kesehatan Dasar 2013).

Notoatmodjo. 2018. Metode penelitian kesehatan. Jakarta : Rineka Cipta.

Proverawati, Atikah dan Erna Kusuma Wati. 2011. Ilmu Gizi Untuk Keperawatan dan Gizi Kesehatan. Yogyakarta : Nuha Medika.

Proverawati, Atikah dan Siti Asfuah. 2009. Buku Ajar Gizi Untuk Kebidanan. Yogyakarta : Nuha Medika.

Puskesmas Ilir Barat I Palembang. Jumlah ibu yang mengalami KEK tahun 2019.

Ratnawati. 2013. Kekurangan Energi Kronis dengan Kejadian Anemia Pada Ibu Hamil di BPS Istiqomah Surabaya.

Setyaningsih. 2015. Konsumsi Besi Folat, Tingkat Kecukupan Energi dan Zat Besi Berhubungan dengan Kejadian 
Anemia Ibu Hamil di Kabupaten Jember.

Sibagariang, Eva Ellya. 2016. Kesehatan reproduksi wanita. Yogyakarta : TIM.

Suhaeti. 2018. Faktor-faktor yang berhubungan dengan status gizi ibu hamil di Wilayah Kerja Puskesmas Lalundu Kabupaten Donggala.

Sukmaningtyas. 2015. Hubungan antara tingkat pengetahuan dan status gizi ibu hamil dengan kejadian anemia di Puskesmas Gatak Kabupaten Sukoharjo.

Susiloningtyas. 2015. Pemberian Zat Besi (Fe) Dalam Kehamilan. Jurnal Fakultas Ilmu Keperawatan Universitas Islam Sultan Agung Semarang.

Syafrudin, Karningsih dan Mardiana. 2011. Untaian materi penyuluhan KIA (Kesehatan ibu dan anak). Jakarta : TIM.

Tari, 2015. Faktor-Faktor Yang Berhubungan Dengan Kekurangan Energi Kronis Pada Ibu Hamil Di Wilayah Kerja Puskesmas Sungai Bilu Banjarmasin.

Unicef. 2019. Laporan PBB. Untuk pertama kalinya angka perempuan dan anak yang bertahan hidup capai tingkat tertinggi. http://www.unicef.go.id, diakses 20 Januari 2020.

Walyani, Elisabeth Siwi. 2008. Asuhan Kebidanan pada Kehamilan. Yogyakarta : PT. Pustaka Baru .

Wiarsih. 2018. Kurang energi kronis, jarak kehamilan, paritas dan kepatuhan konsumsi tablet fe sebagai faktor risiko kejadian anemia pada ibu hamil di Puskesmas Adiwerna Kecamatan Adiwerna Kabupaten Tegal.

Winarsih. 2018. Pengantar ilmu gizi dalam kebidana. Yogyakarta : PT. Pustaka Baru.

Wulandari. 2017. Pengaruh Kekurangan Energi Kronis (KEK) dengan Kejadian Anemia Pada Ibu Hamil di Desa Tumpak Pelem Kecamatan Sawoo Kabupaten Ponorogo.

Yuliastuti. 2018. Faktor-Faktor Yang Berhubungan Dengan Kekurangan Energi Kronis Pada Ibu Hamil Di Wilayah Kerja Puskesmas Sungai Bilu Banjarmasin. 
Jurnal Kebidanan : Jurnal Medical Science Ilmu Kesehatan Akademi Kebidanan Budi Mulia Palembang Volume.11 No.1, Juni 2021

Available online http://iournal.budimulia.ac.id/ 
